\title{
SCENA I PRAWDA NA RONDZIE HISTORII
}

\section{Goffredo FOFI}

Najpiękniejsze powieści, wydane w oficynie E/O, to moim zdaniem Rondo Kazimierza Brandysa oraz Obstugiwatem angielskiego króla Bohumila Hrabala. Polaka i Czecha łączy wiele zarówno na planie ogólnym, jak i strukturalnym. Wydaje się, że wyobraźnia literacka obydwu autorów przenosi się na ich bohaterów i kiedy przedstawienie inscenizowane $\mathrm{w}$ powieści osiąga ten sam stopień euforycznej witalności co przedstawienie, które inscenizuje autor, wówczas powieść rozżarza się cudowną, paradoksalną prawdą.

Pisarze ci, tworząc pod reżimem komunistycznym, nawykli do klimatu kłamstw, nie mieli innego wyboru, niż uprawiać podwójną grę czy rodzaj biernego oporu. U Brandysa nabiera to znaczenia w utworach późniejszych, bezpośrednio sprzed emigracji, nie zaś w tych z wczesnego okresu, które dla odmiany odznaczały się uwewnętrznioną, a niekiedy wynikającą z asekuranctwa zgodnością z ideologicznymi przykazaniami reżimu. (Można by w tym miejscu przeprowadzić porównanie stosowanych metod oporu: czeskich — najczęściej „szwejkowskich” i biernych, ironicznych i pozbawionych przemocy, z metodami polskimi - często przepełnionymi romantycznym buntem, a dodatkowo także węgierskimi - przypominającymi reakcje czeskie, ale w przeciwieństwie do nich i pomimo rewolucji 1956 roku bez skłonności do niszczenia wszystkiego, co marksistowskie. Jednakowoż dyskurs ten wydaje się przedwczesny i nie posiadamy właściwych narzędzi, by móc mu sprostać bez uproszczeń).

Dzięki wydawnictwu E/O miałem szczęście osobiście spotkać zarówno opryskliwego Hrabala, jak i przystępnego, wytwornego Brandysa. Miałem jednak także szczęście być, w ostatnich latach jego życia, przyjacielem innego wielkiego pisarza polskiego - Gustawa Herlinga-Grudzińskiego, wygnańca od późnych lat 50. żyjącego we Włoszech, animatora wydawanej w Paryżu „Kultury”, nielegalnie rozpowszechnianej w Polsce w ciemnych latach stalinizmu. Tak więc Herling, który nie kwestionował mojej sympatii dla Brandysa oraz uznania dla jego późnych utworów, wiele razy mówił, że nie może wybaczyć Brandysowi jego przeszłego zaangażowania w komunizm, a także niektórych jednoznacznie propagandowych utworów (nie były one thumaczone na język włoski, podczas gdy już w późnych latach 50. i wczesnych 60. przekłada się w wydawnictwach Mondadori i Feltrinelli te ostrożnie rewolucyjne, takie jak dość retoryczny utwór Matka Królów czy Obrona „, Grenady”). 
Kiedy także Brandys zdecydował się na uchodźstwo, w Paryżu nawiązał kontakt z Herlingiem i spotkali się kawiarni, bez większego powodzenia. Herling zachowywał się z chłodną uprzejmością, niewzruszenie obstając przy swoim wyroku z przeszłości. Przy pożegnaniu Brandys wypowiedział kwestię, która zaskoczyła Herlinga, ale wyraźnie pokazała, jakie obsesje mogą mieć pisarze: „Musi pan przyznać, że tamta powieść - mówił o swojej najgorszej książce [powieści Obywatele, 1954 — G.F.], z największym przekonaniem opiewającej system komunistyczny narzucony Polsce przez ZSRR — jest jednak bardzo dobrze napisana!”.

Kiedy mury — nareszcie! — runęły, czasopismo „Linea d'ombra” zorganizowało w Mediolanie cykl spotkań pisarzy i intelektualistów z wielu zakątków świata. Najbardziej udanym spośród nich było bez wątpienia spotkanie Brandysa z Christą Wolf. Oboje przyjęli zaproszenie także dlatego, że dotychczas nie mieli okazji się poznać, a bardzo im na tym zależało. Jednak w trakcie tego wieczoru wyczułem pewien fałsz, którym wiało od publiczności — nie od pisarzy, ponieważ oni z pewnością pozostawali szczerzy w swoich stanowiskach i osądach na temat przeszłości i teraźniejszości. Publiczność składała się z „komunistów”, do samego końca przepełnionych ową dziwną hipokryzją włoskiej lewicy, jaka cechowała jej stosunek wobec realnego (i jedynego, niestety) komunizmu. Przeszłość ciążyła, jednak kto doświadczył jej od środka, posiadał znacznie jaśniejsze wyobrażenie - zwłaszcza gdy nie wrzucał wszystkiego do morza przeszłych doświadczeń oraz ideałów młodości: Franca Fortiniego i sympatyków Radia Popolare... Uderzająca jest dla mnie szczególna g o d n o ść, jaka przebijała z wypowiedzi Brandysa i Wolf, odnoszących się do przeszłości, własnego zaangażowania oraz osobistego poczucia obowiązku - całkowite przeciwieństwo powierzchowności i ideologizmów naszych ,prawdziwych rewolucjonistów, prawdziwych marksistów".

Cała twórczość Brandysa, jeśli przyjrzeć się bliżej, odnosi się do przeszłości, ukazując niemożliwość ucieczki od jej uwarunkowań i wyroków, a także konieczność wypracowania strategii — w jego przypadku złożonej i zmiennej — przetrwania, pozwalającej przeżyć na swój własny sposób (zgodnie z wolą wypowiedzenia własnego poglądu na świat, samego siebie oraz innych) wobec nędzy historii, w której — na wschodzie i zachodzie - prawo stanowią zdolne do wszystkiego machiny biurokracji, wyspecjalizowane w kamuflażu, z ich żądzą władzy (albo bezpieczeństwa i uprzywilejowania) i frazesami najwyższych ideałów i najprawdziwszych doktryn. Brandysowi udało się ,zainscenizować” tę złożoność — bohater Ronda „wystawiał” niezłomny heroizm, by zdobyć swoją ukochaną, aktorkę teatralną także nawykłą do obłudy i do odgrywanych entuzjazmów — skończył jednak wciągnięty w „wystawianie” rzeczywistości wymyślonej, by stać się kimś innym, jednak znacznie mniej nikczemnym niż w poprzedniej tożsamości. Nawet jeśli trudno ocenić, ile było przekonania, a ile przedstawienia u Brandysa z wczesnego okresu twórczości, w późniejszym czasie nie był hochsztaplerem; podczas francuskiej emigracji skutecznie dowiódł talentu oraz głębi własnych przekonań. Pisarz wielkiego formatu, jeden z wybitnych twórców minionej epoki, zaszedł tak daleko także dlatego, że zmuszony był do obrachunku z historią, konfrontacji osobistych aspiracji z ciążącymi na nim odpowiedzialnościami, pośród wzlotów i upadków, między zmyśleniem a prawdą.

Tłum. z włoskiego: Wiktoria Wojtyra 